\section{Comissão Europeia Lança Plano de Ação para as Matérias-Primas Essenciais}

Recentemente, a Comissão Europeia apresentou um plano de ação para as matérias-primas essenciais. 0 objetivo deste plano é garantir o acesso da União Europeia a matérias-primas essenciais, reduzindo a dependência da Europa em relação a países terceiros, diversificando o aprovisionamento a partir de fontes primárias e secundárias e melhorando a eficiência de recursos e a circularidade, promovendo em simultâneo um aprovisionamento responsável em todo o mundo.

Com o plano de ação sobre matérias-primas essenciais, a Comissão Europeia delineou dez ações concretas para alcançar essas ambições, sendo a primeira o estabelecimento de uma Aliança Europeia de Matérias-Primas. Esta aliança centrar-se-á principalmente nas necessidades mais prementes, em particular o aumento da resiliência da UE a nível das cadeias de valor das terras raras e ímanes, pois trata-se de um domínio vital para a maioria dos ecossistemas industriais da UE, tais como a energia renovável, a defesa e o espaço.

0 Vice-Presidente Maroš Šefčovič e o Comissário Thierry Breton apresentaram a lista de matérias-primas essenciais para 2020. A lista foi atualizada a fim de refletir

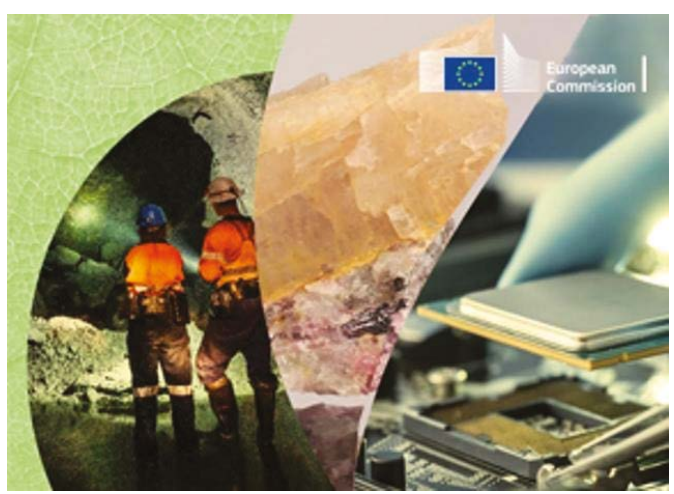

Crédito - Comissão Europeia 2020

a nova importância económica e os desafios de aprovisionamento com base na sua aplicação industrial. A lista adiciona quatro novas matérias-primas essenciais (bauxite, lítio, titânio e estrôncio), perfazendo trinta no total.

Na Tabela Periódica da EuChems que descreve a escassez dos elementos naturais, publicada por ocasião do Ano Internacional da Tabela Periódica 2019, o Lítio e o Estrôncio já estavam listados como elementos em risco de escassez nos próximos 100 anos.

$>$

\section{Bruno Machado}

brunofm@fe.up.pt

\section{Comissão Europeia Adota Nova Estratégia para os Produtos Químicos num Contexto de Sustentabilidade}

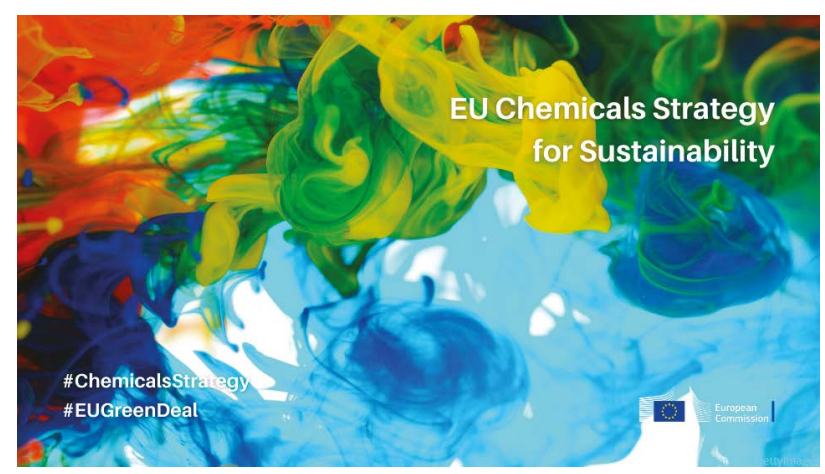

A 14 de outubro de 2020, a Comissão Europeia adotou a Estratégia para a Sustentabilidade dos Produtos Químicos. Esta estratégia faz parte da ambição de assegurar a neutralidade carbónica da União Europeia até 2050, conforme anunciado no Pacto Ecológico Europeu.

Com este plano, a Comissão Europeia reconhece o papel dos produtos químicos para alcançar a transição verde e seus benefícios para o bem-estar Humano, mas também fortalece a regulamentação sobre os produtos químicos mais perigosos e nocivos. A Estratégia da UE para a Sustentabilidade dos Produtos Químicos estabelece ações concretas para um futuro mais seguro e verde.

O principal objetivo da nova Estratégia dos Produtos Químicos é aumentar a proteção do meio ambiente e da saúde humana, com atenção especial para os grupos mais vulneráveis da população. Além disso, irá proibir a utilização das substâncias mais nocivas nos produtos de consumo. A estratégia também permitirá a transição verde deste setor e promoverá padrões 
elevados, bem como a proibição da exportação de produtos químicos interditados na UE.

O comunicado de imprensa da Comissão Europeia sobre a estratégia da UE para a sustentabilidade dos produtos químicos está disponível em: ec.europa. eu/commission/presscorner/detail/en/ip_20_1839.
$>$

Bruno Machado

brunofm@fe.up.pt

\section{IUPAC Anuncia as Dez Principais Tecnologias Emergentes de 2020}

\section{em Química}

A União Internacional de Química Pura e Aplicada (IUPAC) divulgou os resultados da sua pesquisa de 2020 para as dez principais tecnologias emergentes em Química. 0 objetivo deste projeto é demonstrar o valor da Química e informar o público em geral sobre como as ciências químicas contribuem para o bem-estar da sociedade e para a sustentabilidade do Planeta. Seguindo a mesma orientação do ano anterior, o júri selecionou tecnologias emergentes entre novas descobertas científicas e tecnologias totalmente comercializadas, e aquelas com a maior capacidade de abrir novas oportunidades em áreas onde a química desempenha um papel fundamental.

Os finalistas de 2020 são (por ordem alfabética):

- Baterias de ião duplo

- Testes rápidos para diagnóstico

- Emissão induzida por agregação

- Inteligência artificial aplicada à química

- Macronómeros para uma melhor reciclagem de plástico

- Microbioma e compostos bioativos

- Nanossensores

- Química inorgânica de alta pressão

- Tecnología de liquid-gating

- Vacinas de RNA

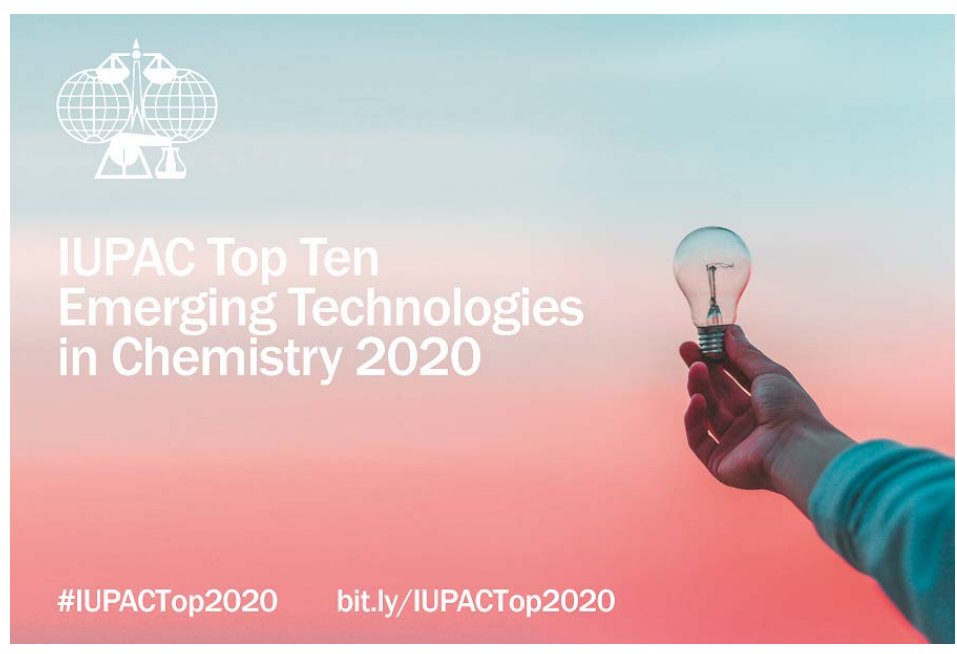

O júri foi constituído por um grupo internacional de especialistas de diferentes áreas que analisou os nomeados e, por fim, selecionou os dez primeiros classificados. Este incluiu Michael Droescher (German Association for the Advancement of Science and Medicine, Alemanha), presidente do júri, Javier García-Martínez (Universidad de Alicante, Espanha), Ray Kookana (CSIRO Land \& Water, Austrália), Ken Sakai (Universidade de Kyushu, Japão) e Bernard West (Life Sciences Ontario, Canadá).

A primeira edição das dez Principais Tecnologias Emergentes em Química foi lançada em 2019 como uma atividade especial e de homenagem ao 100. ${ }^{\circ}$ aniversário da IUPAC. A próxima edição já começou e será liderada novamente pelo Prof. Dr. Michael Droescher.

Para obter mais informações, consulte:

Bruno Machado

iupac.org/what-we-do/top-ten brunofm@fe.up.pt 